\title{
Anne Speckhard
}

\section{Talking to Terrorists. Understanding the Psycho-Social Motivations of Militant Jihadi Terrorists, Mass Hostage Takers, Suicide Bombers \& 'Martyrs'}

\author{
Advances Press, McLean 2012 (wydanie elektroniczne: Amazon), 882 ss.
}

DOI: $10.19195 / 1643-0328.20 .14$

Opracowanie Speckhard to potężny tom liczący niemal 900 stron i 70 rozdziałów, stanowiący ogromne i wartościowe źródło informacji na temat motywacji osób angażujących się w ataki terrorystyczne (ze szczególnym uwzględnieniem zamachów samobójczych oraz brania zakładników), wpływu takich ataków na ich ofiary i otoczenie społeczne, a wreszcie mechanizmów radykalizacji i reprodukcji przemocy politycznej. Jest to efekt dziesięciu lat ciężkiej i często niebezpiecznej pracy: wynik ponad 400 wywiadów przeprowadzonych przez autorkę z terrorystami, ekstremistami, zakładnikami, członkami ich rodzin i znajomymi w kilku państwach. Sama Speckhard proponuje tu trafną metaforę „psychologicznej autopsji” terrorystów-samobójców. Autorka analizuje palestyńskich zamachowców-samobójców, terrorystów Czeczeńskich, belgijskich i marokańskich dżihadystów, londyńskie gangi islamskie oraz opowiada bardzo pouczającą historię jednego z największych programów deradykalizacyjnych, jaki zaprojektowała dla armii amerykańskiej w Iraku. Opracowanie nie ma teoretycznego charakteru, lecz stanowi cenne studium empiryczne, dostarczając mnóstwa materiału badaczom terroryzmu, ekstremizmu i radykalizacji. Z setek wywiadów wyłania się syntetyczny model współpowiązanych czynników, który autorka określa jako „zabójczy koktajl terroryzmu”. Zanim do niego przejdziemy, warto przyjrzeć się bliżej drodze, która doprowadziła do niego autorkę.

\section{Śmierć jako dominanta}

Najczęściej chyba powracające w książce słowa, opisujące motywacje i emocje terrorystów, ich rodzin i znajomych, to upokorzenie, gniew i pragnienie zemsty. Są to główne czynniki uruchamiające "trajektorię terrorystyczną" na poziomie indywidualnym, czyli w istocie katalizujące proces radykalizacji, który kończy się atakiem terrorystycznym. Nie jest oczywiście tajemnicą, że długotrwałe poczucie bezradności i upokorzenie w obliczu wroga mają absolutnie dewastujący efekt psychologiczny. Obserwacja przemocy, której poddawana jest własna rodzina albo nawet przedstawiciele środowiska objętego pojęciem „fikcyjnego pokrewieństwa”, czy doświadczanie takiej przemocy osobiście, to jedne z najsilniejszych indykatorów i predykatorów zaangażowania w szczególnie brutalne formy i akty terroryzmu. Bardzo charakterystyczne jest obsesyjne pragnienie zemsty, które wypiera w zasadzie wszystkie inne dążenia i motywacje, włącznie z ochronną rolą spełnianą przez instynkt samozachowawczy. To swoiste „bycie ku śmierci” staje się refrenem książki, pojawiając się raz za razem w różnych kontekstach. Obracamy się tu w środowiskach socjopolitycznych, w których śmierć staje się dominantą, punktem odniesienia, a w końcu obiektem obsesji, kultu, naczelnym pragnieniem i dążeniem. Jest narzędziem paliatywnym, pozwalającym uwolnić się od bólu psychicznego, upokorzenia, powracających traumatycznych wspomnień. Co charakterystyczne, ten destrukcyjny mechanizm psychologiczny jest cynicznie wykorzystywany do celów politycznych i ideologicznych przez ugrupowania stosujące terroryzm. Samozagłada realizowana z reguły w stanie hiperpobudzenia i dysocjacji, pełni kilka 
funkcji z punktu widzenia osoby jej dokonującej: jest heroicznym aktem obrony swojej wspólnoty, aktem odwetu przywracającym zachwiany "porządek naturalny” (równowagę moralną), aktem ekspresji pozwalającym na wyrażenie swego bólu i - ostatecznie - ucieczkę od niego. „Operacje męczeńskie” na poziomie społecznym i politycznym to użyteczne narzędzia walki, ale na poziomie indywidualnym to psychologiczny mechanizm ucieczkowy: samobójstwo w islamie jest bezwzględnie zakazane, ale „męczeństwo” to swoista „furtka”, „wyjście awaryjne”.

\section{Traumatyzacja pośrednia i fikcyjne pokrewieństwo}

Zjawiskiem, na które autorka zwraca szczególnie baczną uwagę, jest traumatyzacja pośrednia, będąca skutkiem ekspozycji na przemoc i okrucieństwo wobec osób, z którymi odczuwa się więź emocjonalną. Dostęp do informacji jest tu czynnikiem o szczególnie istotnym znaczeniu. Bycie świadkiem przemocy w strefie konfliktu to wystarczający czynnik motywującym do działań terrorystycznych, a telewizja i Internet to wyjątkowo skuteczne media, jeśli chodzi o ich potencjał traumatyzujący. W licznych wywiadach relacjonowanych przez autorkę powraca wątek traumatyzacji pośredniej - zarówno „niekierowanej” (będącej efektem ubocznym „normalnej” ekspozycji na przekazy medialne), jak i „celowanej” (stanowiącej fragment procesu radykalizacji i rekrutacji organizowanego przez ugrupowania i siatki ekstremistyczne). Grupy terrorystyczne są bardzo sprawne nie tylko w wykorzystywaniu, ale także w wywoływaniu pośredniej traumatyzacji oraz gniewu i pragnienia zemsty, używając zwłaszcza materiałów dokumentujących na wideo szczególnie dramatyczne i drastyczne sytuacje. Mamy tu do czynienia ze szczególnie potężnym wzmacniaczem motywacyjnym, a niektóre obrazy nabierają statusu ikon (czy mówiąc internetowym żargonem: memów), stając się potężną bronią symboliczną i narzędziem mobilizacji. Ów mechanizm działa dzięki wspomnianemu zjawisku „fikcyjnego pokrewieństwa”. Zastępcza czy fikcyjna rodzina w postaci wielkiej wspólnoty religijno-kulturowej, środowiska społecznego albo grupy terrorystycznej, zyskuje przy tym na atrakcyjności w sytuacji, w której prawdziwa rodzina ma charakter dysfunkcjonalny, stanowiąc przyczynę rozczarowania, traumy, czy upokorzenia. Przemoc stosowana w rodzinie w roli narzędzia socjalizującego i dyscyplinującego ma swoje konsekwencje nie tylko w wymiarze socjologicznym, ale ostatecznie także społecznym i politycznym. Widoczny jest przy tym szczególnie toksyczny mechanizm „hierarchii przemocy”, kształtujący sposób postrzegania świata jako miejsca, w którym rządzi brutalna siła, mierzona zdolnością do upokarzania i zadawania bólu. W ten sposób przemoc ulega kulturowej normalizacji: jeśli ekstremiści polityczni sugerują wykorzystanie jej jako narzędzia walki politycznej, z pewnością łatwiej to w takiej kulturze zaakceptować.

\section{Patologiczne środowiska socjokulturowe?}

Jednym z kluczowych elementów radykalizacji do przemocy jest - mówiąc językiem psychodynamicznym - ujawnianie się potrzeby empatii w sposób zwyrodniały w sytuacji, w której czynniki kulturowe i polityczne uniemożliwiają jej normalne zaspokajanie. Potrzeba osiągnięcia współodczuwania to motyw, który powtarza się w kolejnych relacjach i wywiadach niczym mantra. Humanizacji i potrzebie empatii towarzyszy równie silna potrzeba podkreślania różnic między „nami” a „nimi”, która ostatecznie na ogół przyjmuje formułę dehumanizacyjną.

Z relacji rozmówców Speckhard wyłania się obraz konfliktów zapętlonych w klinczu wzajemnych oskarżeń i traum, anatomia patologicznych kultur, normalizujących przemoc i nienawiść, 
w których mechanizmy kanalizujące i neutralizujące destrukcyjne impulsy uległy atrofii lub nie okazały się wystarczająco wydolne, by sprostać narastającej presji. Warto przy tym pamiętać, że termin „patologiczny” nie odnosi się wyłącznie do jakichś szczególnych wewnętrznych, „autonomicznych" własności tych kultur i nie może być interpretowany jako narzędzie zbiorowej stygmatyzacji. Należy mieć na uwadze fakt, że szczególnie dotkliwe patologie są skutkiem toksycznych oddziaływań między społecznościami (a czasem miedzy różnymi orientacjami w obrębie tej samej kultury), zwłaszcza rodzących długotrwałą ekspozycję na przemoc, pogardę, upokorzenia i często instytucjonalnie sankcjonowaną dehumanizację. Eksplozje przemocy politycznej w badanych przez Speckhard kontekstach wydają się stanowić efekt połączenia wewnętrznych uwarunkowań i norm kulturowych, utrudniających uporanie się z rozmaitymi frustracjami, napięciami, deficytami oraz dysfunkcji wynikających z destrukcyjnych, wrogich kontaktów z innymi kulturami. Przykładem może być restrykcyjność seksualna i wynikające z niej patologie w połączeniu z postrzeganą "rozwiązłością” europejskich kobiet czy powszechna traumatyzacja na skutek ekspozycji na przemoc połączona $z$ brakiem infrastruktury pomocy psychologicznej i brakiem kulturowej akceptacji na korzystanie z takiej pomocy. To właśnie owe toksyczne połączenia wytwarzają szczególnie nasycone przemocą środowiska społeczno-kulturowe. Faktu, że około 20\% ludności palestyńskiej cierpi na PTSD, nie da się wytłumaczyć specyfiką lokalnej kultury. Speckhard trafnie zauważa, że w sytuacji braku dostępu do pomocy psychologicznej ludzie radzą sobie, odwołują się do innych, często „awaryjnych” i desperackich metod, uciekają w narkotyki, fantazje, ideologie i działania obiecujące honorową ucieczkę od życia. Ekspozycja na przemoc zwiększa gotowość do akceptacji i stosowania przemocy, co wytwarza sprzężenia zwrotne znane w postaci spirali eskalacyjnych i niekończących się konfliktów przenikniętych coraz bardziej nieprzejednaną nienawiścią, wpisaną trwale w tożsamość danych społeczności. Takie środowiska społeczne same w sobie stają się „maszynami radykalizacyjnymi”: życiowe doświadczenia (ekspozycja bezpośrednia i pośrednia), procesy socjalizacji, narzędzia komunikacji społecznej i obowiązujące normy powodują, że „celowane” działania radykalizacyjne stają się zbędne lub drugorzędne. Z tego właśnie powodu młodych Palestyńczyków tak łatwo aktywować do misji samobójczej: długie przygotowania i indoktrynacja są zbędne, ponieważ środowisko społeczne działa jak katalizator radykalizacji.

\section{Kolektywna doktryna konieczności — uzasadnienia moralne i instrumentalne}

Efektem poczucia osaczenia, niesprawiedliwości, braku pola manewru, jest charakterystyczna dla ugrupowań terrorystycznych i wspierających ich grup referencyjnych „kolektywna doktryna konieczności", skonstruowana $\mathrm{z}$ wielu uzasadnień i racjonalizacji własnej przemocy: instrumentalnych (taktycznych, strategicznych, politycznych), ale przede wszystkim moralnych. Na pierwszy plan wysuwa się tu instynktownie akceptowana konieczność reakcji defensywnej na zadawane „nam” lub „tym, których mamy obowiązek bronić” niesłusznie cierpienia. Uzasadnienia taktyczne i strategiczne w ramach „kolektywnej doktryny konieczności” odwołują się z kolei do asymetrii potencjałów stron konfliktu, przymusu wynikającego z braku dostępu alternatywnych metod i narzędzi walki i jako takie są bezpośrednio powiązane z argumentacją moralną. Cytując palestyńskich bojowników Hamasu z Gazy: „Jedyne rozwiązanie to walczyć w ten sposób. Między nami nie ma równowagi sił. Nie mamy czołgów ani helikopterów Apache. To brutalna siła. Mamy tylko prostą broń. Mamy tylko kałasznikowy [...] Jedyny sposób, aby z nimi walczyć, to eksplodować, używając naszych własnych ciał” (8153). Generalnie rzecz biorąc, zarówno uzasadnienia moralne, jak i instrumentalne w ramach „kolektywnej doktryny konieczności” trak- 
tują różnice między celowym zabijaniem cywilów a tak zwanymi ofiarami ubocznymi (collateral damage) i ofiarami cywilnymi, wynikającymi z planowego represjonowania ludności cywilnej, jako wytworzone przez technikę propagandową silniejszej strony konfliktu. Jest to próba przeciwstawienia się zabiegom mającym na celu konstruowanie antagonizmu przez przeciwnika w taki sposób, aby uzyskać w jego ramach moralną przewagę. Na płaszczyźnie moralnej wskazuje się zwłaszcza na barbarzyństwo i okrucieństwo wroga, jego agresywną postawę i rolę inicjatora konfliktu oraz własną bezbronność w obliczu nierównych sił i biernej postawy otoczenia. $\mathrm{Na}$ płaszczyźnie instrumentalnej argumentacja sprowadza się do braku alternatywnych narzędzi i możliwości obrony. Zamachowcy-samobójcy stają się w takiej narracji używanym z konieczności funkcjonalnym ekwiwalentem amunicji precyzyjnej, a ataki na cele cywilne jedynym realnym narzędziem wywierania presji na wrogu i równoważenia sił.

\section{Radykalizacja poza strefami konfliktu}

Kiedy Speckhard wychodzi ze środowisk bezpośrednio objętym międzygrupowym konfliktem z użyciem przemocy, wagi nabierają nieco inne mechanizmy i czynniki motywacyjne. Radykalizacja w takich kontekstach jest procesem bardziej świadomie kierowanym i planowanym. Używa się do tego istniejących wcześniej, łatwych do zidentyfikowania „słabych punktów” osób wytypowanych jako kandydaci, dość prostych w zastosowaniu technik manipulacji emocjami oraz takich metod jak ramowanie i torowanie (zwłaszcza przy użyciu specjalnie przygotowanych materiałów wideo). Speckhard argumentuje, że w większości wypadków (nie dotyczy to konwertytów) nie można tu mówić o radykalnej rekonstrukcji przekonań, lecz raczej o uwypukleniu już wcześniej istniejących zespołów poglądów i nastawień. W tego typu środowiskach znaczenia nabierają "podżegacze terrorystyczni”: osoby zajmujące się inicjacją i podtrzymywaniem procesów radykalizacji, czyli de facto katalizowaniem i legitymizacją uzasadnianej ideologicznie przemocy. Imigranci żyjący w obcym, wrogim środowisku, wśród ludzi o uprzedzeniach antyislamskich, nie czują się bezpiecznie i nie mają perspektyw, a jednocześnie wykazują silny opór przed oczekiwaniami asymilacyjnymi. Pojawiają się w tej sytuacji frustracja i deficyt godności. Gdy werbownik argumentuje, że świat Zachodu jest zepsuty i nieczysty, silnie rezonuje to $\mathrm{w}$ ich istniejących już przekonaniach i doświadczeniach. Stopniowo dochodzi się do akceptacji przemocy jako narzędzia rozwiązującego problemy indywidualne i grupowe. W ten sposób przemoc staje się immanentnym, kompatybilnym elementem struktury narracyjnej, jej logiczną puentą.

\section{Program deradykalizacyjny w Iraku}

Ostatnim, obszernym komponentem książki jest relacja z udziału autorki w Programie Rehabilitacji Zatrzymanych w Iraku, realizowanym z inicjatywy armii amerykańskiej w 2007 roku. Osoby zainteresowane programami i procesami deradykalizacji znajdą tu wiele interesujących informacji, zważywszy, że przedsięwzięcie to projektowano na wielką skalę: uczestniczyło w nim w jakiejś formie ponad 10 tysięcy irackich więźniów. Przez deradykalizację rozumiano tu doprowadzenie zatrzymanego do punktu, w którym wyrzeknie się jakiegokolwiek zaangażowania w przemoc przeciwko armii USA, rządowi irackiemu lub przemoc sekciarską i nie będzie uważał przemocy za właściwy czy moralny wybór. W zasadzie zaprojektowano tu trzy programy: sześciotygodniowy Redirect from the Militant Jihad (dla około 20\% zatrzymanych, osób silnie przekonanych, że przemoc jest uzasadniona), trzytygodniowy Psych Lite - dla umiarkowanych, czyli większości 
więźniów (zaangażowanych uprzednio w przemoc, ale bez internalizacji radykalnych przekonań) i sześciotygodniowy Juvenile Protect Program dla zatrzymanych mających poniżej 18 lat (800 osób), uwzględniający między innymi sport i zajęcia szkolne. W gruncie rzeczy Speckhard relacjonuje tu dość przygnębiające zderzenie idealistycznych oczekiwań z biurokratyczną rzeczywistością i ignorancją. Przedsięwzięcie naszkicowano niezwykle ambitnie: miało trwać 6 tygodni i łączyć komponent deradykalizacyjny (składający się z kolei z części religijnej i psychologicznej) oraz wojskowy program walki $z$ analfabetyzmem, edukacji obywatelskiej i szkoleń mających zwiększyć szanse zatrudnienia zatrzymanych po ich wypuszczeniu. Niestety, presja rządu Iraku na USA w celu jak najszybszego zwolnienia zatrzymanych uniemożliwiła realizację ambitnych planów i w rzeczywistości wielu więźniów zwalniano już po czterodniowej wersji programu. Generalnie realizacja projektu w relacji Speckhard przypominała festiwal pomyłek i niekompetencji, a ostatecznie jego autorka została $\mathrm{z}$ niego wyeliminowana w dość bezceremonialny sposób. Trzeba jednak przyznać, że trudno było sprawnie zrealizować tak szeroko zakrojone przedsięwzięcie w kraju, w którym pozostało tylko 60 psychiatrów i w zasadzie żadnych psychologów.

Speckhard trafnie rozpoznaje problemy związane z deradykalizacją, a jej koncepcja połączenia ideologicznej (religijnej) wojny narracji (dekonstruowanie narracji ekstremistów przy użyciu kompetentnych ekspertów) z pomocą psychologiczną wydaje się dobrze umocowana na gruncie dotychczasowej wiedzy o procesach deradykalizacyjnych. Jak słusznie zauważa autorka, jeden z najtrudniejszych problemów polega na tym, że zinternalizowana ideologia doskonale pasuje do potrzeb osób straumatyzowanych i zagubionych, oferując możliwość ujścia dla gniewu, uzasadnienie przemocy i znaczenie zarówno dla życia, jak i śmierci. Porzucenie ideologii wytwarza pustkę i może cofnąć osobę do stanu bezsilnej desperacji i beznadziei oraz głębokiego poczucia winy, jeśli popełniała ona zbrodnie. Gdy rzuca się zatem wyzwanie takim przekonaniom, należy znaleźć coś, co wpłynie także na poczucie celu i własnej wartości, aby zastąpić to, co się odbiera. Potrzebne są psychologiczne podstawy deradykalizacji: narzędzia umożliwiające przepracowanie gniewu, żalu, traumy i wszystkich emocji, które otworzyły dane osoby na radykalną ideologię. Jak pisze autorka, „musisz być z nimi, być im świadkiem, współodczuwać z nimi i pomóc im ponownie uzyskać połączenie $\mathrm{z}$ ich człowieczeństwem, aby mogli wybrać inaczej - wybrać niestosowanie przemocy" (loc. 14941).

\section{Konkluzje}

Jakie wnioski wyciąga Speckhard z dziesięciu lat badań i ponad 400 wywiadów? Jej synteza to „zabójczy koktajl terroryzmu”, który powstaje z połączenia czterech składników: grupy terrorystycznej, podatnych jednostek, wsparcia społecznego i ideologii terrorystycznej. Należy mieć na uwadze, że trajektoria terroryzmu na poziomie motywacyjnym działa nieco inaczej w strefach konfliktów zbrojnych i poza nimi. W tych pierwszych ogromne znaczenie wydają się mieć trauma, utrata bliskich i pragnienie zemsty (ataki samobójcze jawią się jak reakcja ucieczkowa w kontekście niemożliwego do zniesienia cierpienia psychicznego). W drugich z kolei kluczowe są: marginalizacja społeczna, alienacja i traumatyzacja pośrednia, a także pragnienie udowodnienia własnej męskości, pragnienie przynależności, ochrony innych członków wspólnoty, przygody i zdobycia statusu bohatera społeczności. W obu kontekstach pojawiają się dwa niezwykle istotne czynniki: upokorzenie i frustracja. Istotnymi zmiennymi są też poziom akceptacji przemocy w domach rodzinnych i nasycenie nią otoczenia społecznego.

Oczywiście, granice między tymi dwoma typami środowisk są dość płynne. Na przykład werbownicy działający poza strefami konfliktu „importują” przemoc, traumę i żal powszechne w stre- 
fach konfliktu poprzez zdjęcia, filmy i inne materiały dostępne w Internecie. Gdy święte dla danej społeczności wartości są deptane w dowolnej strefie (konflikt lub poza konfliktem), jak w wypadku publikacji karykatur Mahometa, bezczeszczenia Koranu itd., może to silnie motywować ludzi do przemocy. Poza tym enklawy skrajnej przemocy mogą występować w generalnie pokojowych strefach, jak dzielnice miast opanowane przez gangi czy nawet rodziny, w których stosuje się przemoc. Fanatyzm religijny jest często powiązany ze skumulowanymi doświadczeniami traumatycznymi, które ułatwiają akceptowanie ideologii terrorystycznej. Jak konstatuje Speckhard: „Terroryści, których badałam nie byli szalonymi zabójcami. Zamiast tego byli racjonalnymi aktorami, gdy rozważamy ich wybory w ramach kontekstu ich wierzeń religijnych. Wielu z nich jednak zwłaszcza w strefach konfliktu - chociaż nie było szalonych, było z pewnością psychologicznie zaburzonych (disturbed), zwłaszcza w wyniku traumy psychologicznej i żałoby” (loc. 15948).

Speckhard jest na ogół trzeźwym i rozsądnym analitykiem rzeczywistości. Autorka rozumie ogromne znaczenie kontekstu społecznego i politycznego. „Potrzeby i podatności są definiowane głównie przez psychospołeczne, kulturowe, organizacyjne i polityczne konteksty, w których żyją jednostki, a zatem musimy zrozumieć i zająć się tymi kontekstami, aby zrozumieć narodziny terrorysty i by przyczynić się do jego odejścia od terroryzmu" (loc. 15934). Zauważa wreszcie, że „islam sam w sobie nie jest problemem. Wszystkie religie mogą być zniekształcone, by promować fanatyzm, a grupy, które przyjmują zniekształcone poglądy religijne, mogą przekonać swe kadry, że są oni ,kosmicznymi wojownikami' [pojęcie zaczerpnięte od Marka Juergensmeyera - B.B.] zaangażowanymi w bitwę zaordynowaną przez Boga w imię religii i skoro tak, to uzasadnione są ekstremalne środki” (loc. 15977-15992).

Książka Speckhard nie jest doskonała i wielu specjalistów uzna ją za momentami irytującą w lekturze hybrydę opracowania naukowego i czegoś w rodzaju pamiętnika czy reportażu, w którym autorka z niewiadomych przyczyn dzieli się z czytelnikami opisami zachodów słońca, ubioru swoich rozmówców czy detalami dotyczącymi swoich relacji małżeńskich i pozamałżeńskich. Staranniejsza praca redaktorska umożliwiłaby znaczne zredukowanie objętości pracy i nadanie jej bardziej spójnego charakteru. Speckhard wykazuje także dziwne wahania między przenikliwością i profesjonalizmem a naiwnością i tendencją do - mówiąc żargonem antropologów - utożsamiania się z „tubylcami” (going native): „I wtedy to czuję: przytłaczający gniew i upokorzenie i pragnienie oddania ciosu, kotłujące się we mnie. [...] To już nie ja, Amerykanka, badająca ich. Ja jestem nimi” (loc. 9397-9415).

Jako na wykwalifikowanego psychologa, świetnie wyposażonego w narzędzia badania religijnego ekstremizmu, Speckhard wykazuje też zaskakująco niewielką zdolność do krytycznej introspekcji, nękając czytelnika swoimi teistycznymi wynurzeniami („Bóg zawsze daje nam to, czego potrzebujemy, gdy go wzywamy") i pozwalając się bezkrytycznie uwodzić religijnemu instrumentarium psychologicznej manipulacji. Podsumowując wypowiedź jednego z młodych dżihadystów czeczeńskich na temat raju jako miejsca przeznaczenia męczenników, Spekhardt słusznie analizuje ją w kategoriach religijnej mentalności urojeniowej, niepokojące jest jednak to, że sama z pełną powagą dzieli się z czytelnikami własnymi urojeniami. Pominąwszy fragmenty zbędne i podobne natręctwa, praca Speckhard zawiera ogromną liczbę użytecznych informacji uzyskanych z pierwszej ręki i żadna osoba zainteresowana profesjonalnie problematyką psychologii terroryzmu nie powinna jej pominąć.

Bartosz Bolechów 